\title{
Antifungal activity of selected essential oils against Fusarium culmorum and F. graminearum and their secondary metabolites in wheat seeds
}

\author{
Adam Perczak ${ }^{1} \cdot$ Daniela Gwiazdowska ${ }^{2} \cdot$ Katarzyna Marchwińska $^{2} \cdot \mathrm{Krzysztof} \mathrm{Juś}^{2} \cdot$ Romuald Gwiazdowski $^{3}$. \\ Agnieszka Waśkiewicz ${ }^{1}$
}

Received: 2 January 2019 / Revised: 5 May 2019 / Accepted: 10 May 2019 / Published online: 23 May 2019

(c) The Author(s) 2019

\begin{abstract}
Essential oils (EOs) are products of plant origin and include mixtures of different chemical compounds. These volatile substances have many interesting properties, including antifungal properties. Fungi may develop under field conditions on crops such as wheat or corn and are able to synthesize mycotoxins, which adversely affect livestock and human health. In the present study, selected EOs were used to inhibit the growth of Fusarium graminearum and F. culmorum and reduce the concentrations of mycotoxins in wheat grain. The EOs significantly inhibited the growth of tested Fusarium species (90.99-99.99\%), as determined based on ergosterol quantitative analysis. Only the addition of orange oil to F. culmorum exhibits a different inhibition capacity (68.13\%). EO application resulted in a large reduction in zearalenone content (99.08-99.99\%); only in the case of orange oil application was the reduction estimated at approximately $68.33 \%$. However, all EOs provided a significant reduction in the concentration levels of group B trichothecenes (94.51-100\%). It can be concluded that EOs inhibit the growth of fungi of the genus Fusarium and reduce concentration levels of the mycotoxins zearalenone and group B trichothecenes.
\end{abstract}

Keywords Antifungal activity · Essential oils · Fusarium spp. E Ergosterol · Zearalenone $\cdot$ Trichothecenes $\cdot$ Wheat grain

\section{Introduction}

Several species of the Fusarium genus, including Fusarium culmorum and $F$. graminearum, are causative agents of severe plant diseases that are responsible for significant economic losses in crops worldwide every year (Scherm et al. 2013; Ellis and Munkvold 2014; Avanço et al. 2017).

Communicated by O. Kniemeyer.

Adam Perczak

adampe_89@o2.pl

1 Department of Chemistry, Poznań University of Life Sciences, Wojska Polskiego Street 75, Poznań 60-625, Poland

2 Department of Natural Science and Quality Assurance, Faculty of Commodity Science, Poznań University of Economics and Business Poznań, Niepodległości Avenue 10, Poznań 61-875, Poland

3 Department of Pesticide Investigation, Institute of Plant Protection, National Research Institute, Władysława Węgorka Street 20, Poznań 60-318, Poland
Moreover, their secondary metabolites, mycotoxins, are characterized by a wide spectrum of toxic effects (carcinogenic, mutagenic, teratogenic or oestrogenic effects), causing acute and chronic diseases in animals and humans (Zain 2011; da Cruz et al. 2013; Assunção et al. 2016). Mycotoxins are low molecular mass compounds; however, their chemical structures vary considerably. The dominant mycotoxins produced by $F$. culmorum and $F$. graminearum are zearalenone (ZEA) and deoxynivalenol (DON) and their derivatives; these mycotoxins are often identified in different cereals contributing to reduction in grain quality (Waśkiewicz et al. 2008; Goliński et al. 2010; Döll and Dänicke 2011; Zaied et al. 2012; Covarelli et al. 2015; Franco et al. 2018; Piacentini et al. 2018).

Due to their harmful effects on animal and human health as well as the need to ensure food and feed safety, there is a constant need to control fungal growth and mycotoxin production in crops. Although integrated plant protection includes a combination of various strategies, chemical fungicides still play the most significant role in the growth control of mycotoxigenic fungi. However, studies on pesticide toxicity based on the databases of the EPA, IARC, WHO, 
and Pesticide Action Network indicate that synthetic fungicides may cause some adverse (carcinogenic, endocrine disrupting, reproductively and developmentally toxic, acutely toxic) effects on humans (Mesnage et al. 2014; Nicolopoulou-Stamati et al. 2016). Moreover, these compounds have negative influences on the environment, including water, soil and air contamination, as well as toxic effects on non-target organisms (da Cruz et al. 2013). Therefore, in recent years, there has been increasing interest in searching for biological antifungal agents to replace synthetic pesticides. Among natural antimicrobial products, particularly interesting are plant products such as essential oils (EOs), which are some of the most promising phytochemicals and can be used for the preservation of cereals and their products (Singh et al. 2010; Boukaew et al. 2017; Foltinová et al. 2017; Gakuubi et al. 2017).

EOs are aromatic, complex, volatile, oily liquids obtained from different parts of plants (leaves, bark, stems, seeds, roots, flowers, buds, and fruits) belonging to families such as Alliaceae, Lamiaceae, Pinaceae, Apiaceae, Rutaceae, and Lauraceae (Bozin et al. 2006; Tumen et al. 2010; Shannon et al. 2011; Solorzano-Santos and Miranda-Novales 2012; Calo et al. 2015). EOs are mixtures of over 20 groups of chemical compounds, such as terpenes, alcohols, acids, esters, epoxides, aldehydes, ketones, amines, and sulfides. Their composition depends on several factors, including species and part of the plant, geographic region, agriculture method, and extraction method (Feng and Zheng 2007; Bakkali et al. 2008; da Cruz et al. 2013; Raut and Karuppayil 2014).

A number of scientific investigations have proved the antimicrobial activity of EOs derived from various herbs and plants, including their biological activity towards many fungal plant, animal and human pathogens (Lang and Buchbauer 2012; Boire et al. 2016; Grata 2016; Kumar et al. 2016; Gabriel et al. 2018). The antifungal mechanism of action of EOs is not yet completely understood. It is worth mentioning that terpenoids and phenolics, which are major components of EOs, play a crucial role in EO antimicrobial activity. Due to their lipophilic nature and low molecular weight, these compounds are able to cause structural and functional damage in the cell of microbes by disrupting the membrane permeability and the osmotic balance of the cell (Kalagatur et al. 2015; Prakash et al. 2015; Grata 2016). Moreover, some EOs may inhibit the action of some enzymes, including mitochondrial enzymes such as lactate, malate, and succinate dehydrogenases. These enzymes are involved in ATP biosynthesis (Chen et al. 2013; Nazzaro et al. 2017) as well as $\mathrm{H}^{+}$-ATPase activity; inhibiting these processes leads to intracellular acidification and cell death (Ahmad et al. 2013). The inhibition of mycelial growth also depends on the concentration of EOs (Dambolena et al. 2010; Gömöri et al. 2013;
Sumalan et al. 2013; Kumar et al. 2014; Elgorban et al. 2015; Perczak et al. 2016). In addition, a majority of plant EOs display high biological safety and are classified as "generally recognized as safe" (GRAS) by the Food and Drug Administration (FDA) (Kedia et al. 2014).

Many studies in recent years have focused on the antifungal potential of EOs against Aspergillus and Fusarium genera, mainly on cereal matrices such as rice, oat, maize or wheat (Fandohan et al. 2004; Marin et al. 2004; Velluti et al. 2004; Sumalan et al. 2013; Esper et al. 2014; Prakash et al. 2015; Kumar et al. 2016; Santamarina et al. 2016; Tagne et al. 2016; Tian et al. 2016; Boukaew et al. 2017; Bozik et al. 2017). However, the available literature provides limited data concerning comprehensive studies on the effect of EOs on the inhibition of both Fusarium growth and mycotoxin biosynthesis.

Thus, the main aim of the present study was to determine the antifungal activity of selected EOs and, consequently, mycotoxin biosynthesis inhibition in wheat grain. In our research, we tested (1) the antifungal effect on chosen Fusarium species of eight selected EOs of different origin, and (2) the influence of EOs on the growth of two mycotoxigenic Fusarium strains (F. culmorum and $F$. graminearum) on sterile wheat grain, determined by analysis of the concentrations of ergosterol (as selective fungal indicator), zearalenone, and deoxynivalenol with derivatives (as toxic secondary metabolites of Fusarium genus).

\section{Materials and methods}

\section{Plant material}

Wheat grain (Fortuna variety) was obtained from the Department of Pesticide Investigation, Institute of Plant Protection-National Research Institute in Poznań, Poland. The samples of $25 \mathrm{~g}$ were mixed with a small amount of water ( $10 \mathrm{~cm}^{3}$ to prevent sample burning during sterilization) in Erlenmeyer flasks and sterilized at $121^{\circ} \mathrm{C}$.

\section{Fusarium strains}

Fusarium graminearum strain KZF1 (elsewhere referred to as $F$. graminearum) and $F$. culmorum strain KZF5 (elsewhere referred to as $F$. culmorum) were obtained from the collection of the Department of Pesticide Investigation, Institute of Plant Protection-National Research Institute in Poznań, Poland. Tested strains were incubated at $25^{\circ} \mathrm{C}$ in Petri dishes ( $9 \mathrm{~cm}$ diameter) on PDA (Potato Dextrose Agar, BioShop, Canada) for 5-7 days. 


\section{Standards, chemicals, and reagents}

Group B trichothecenes (deoxynivalenol, 3- and 15-acetyldeoxynivalenol, nivalenol, and fusarenon $\mathrm{X}$ ), zearalenone, and ergosterol-certified standards and solvents for analysis (HPLC grade) were purchased from Sigma-Aldrich (Steinheim, Germany). All chemicals used for mycotoxin extraction and purification were purchased from POCh (Gliwice, Poland). Water for the HPLC mobile phase and trichothecene extraction was purified using the Milli-Q system (Millipore, Bedford, MA, USA). Trimethylsilyl imidazole, trimethylchlorosilane, and Tween 80 were also purchased from Sigma-Aldrich (Steinheim, Germany).

\section{Essential oils (EOs)}

The objects of the study were eight selected EOs: cinnamon bark (Cinnamomum zeylanicum, Indonesia), oregano herb (Origanum vulgare, Mediterranean countries), palmarosa leaves (Cymbopogon martini, India), orange peel (Citrus aurantium dulcis, Brazil), verbena leaves and flowers (Thymus hiemalis, Spain), spearmint leaves (Mentha viridis, China), fennel seeds (Foeniculum vulgare dulce, Russia/Bulgaria), and rosewood (Aniba rosaeodora, India). EOs were obtained from Ecospa Rita Kozak-Chaber Artur Chaber s.c., Poland and from Zrób Sobie Krem-Kosmetyki Naturalne Katarzyna Damętka-Zomerfeld, Poland. Solutions of EOs ( $20 \%$ concentration) were prepared by mixing the certified reference material with water and Tween 80 $(10 \%)$ as an emulsifying agent.

\section{Evaluation of antifungal activity of EOs}

The antifungal effect of tested EOs was determined by disc diffusion assay (El Ouadi et al. 2017; Munhuweyi et al. 2017). First, conidia suspensions were prepared by harvesting the conidia from fresh cultures on Petri plates and mixing with $10 \mathrm{~cm}^{3}$ of sterile saline. The conidia concentration was adjusted to approx. $10^{6}$ conidia $/ \mathrm{cm}^{3}$ by enumerating using a haemocytometer chamber. The $100 \mu \mathrm{l}$ conidia suspensions were spread on PDA Petri plates with a sterile glass spreader. Next, $10 \mu \mathrm{l}$ aliquots of EOs was individually loaded into 6-mm-diameter sterile paper discs (WhatmanTM, USA) and placed on a Petri dish. The fungal cultures with discs soaked with EOs were incubated at $25 \pm 2{ }^{\circ} \mathrm{C}$ for $5-7$ days, depending on the indicator microorganism. After incubation, the inhibition zones were measured. All experiments were performed in triplicate, and the results are presented as an average of three replications.

\section{Determination of minimum inhibitory concentration}

The minimum inhibitory concentration (MIC) of EOs was determined by the microdilution method (Stupar et al. 2014; Gwiazdowski et al. 2018). Serial, twofold dilutions of the EOs (v/v) were prepared in 96-well microtiter plates in PDB (potato dextrose broth). Next, conidia suspensions of Fusarium strains, prepared as described above, were introduced into the wells in equal amounts. The plates were incubated at $25 \pm 2{ }^{\circ} \mathrm{C}$ for 5-7 days, depending on the indicator organism. The MIC was defined as the lowest concentration of EO that completely inhibited visible growth after incubation.

\section{Effect of EOs on the growth of Fusarium isolates and mycotoxin production}

The effect of EOs on the growth of Fusarium fungi on wheat was investigated using the method described by Shi et al. (2014) with some modifications. Each EO solution $\left(5 \mathrm{~cm}^{3}\right)$ was mixed with $25 \mathrm{~g}$ of sterile wheat grain in an Erlenmeyer flask. The mixture was vigorously stirred. Then, three rings $(6 \mathrm{~mm})$ of solid culture of the pathogen $(F$. graminearum or $F$. culmorum) were added to each Erlenmeyer flask and mixed. Solutions of Tween 80 and deionized water were added to the control samples without the addition of EO. Next, the prepared mixtures were stored in the dark at $25^{\circ} \mathrm{C}$ for a period of 28 days. After incubation, samples were dried, milled, homogenized and prepared for chromatographic analysis.

\section{Chemical analysis}

\section{Ergosterol (ERG)}

Homogenized grain samples (100 mg) were suspended in $2 \mathrm{~cm}^{3}$ of methanol in a culture tube and treated with $0.5 \mathrm{~cm}^{3}$ of $2 \mathrm{M}$ aqueous sodium hydroxide (Perczak et al. 2016). Tightly sealed samples were irradiated three times in a microwave oven $(370 \mathrm{~W})$ for $10 \mathrm{~s}$ and then neutralized with $1 \mathrm{~cm}^{3}$ of $1 \mathrm{M}$ aqueous hydrochloric acid. Samples were extracted with $n$-pentane $\left(3 \times 4 \mathrm{~cm}^{3}\right)$ and transferred to the vials. Extracts were evaporated to dryness in a stream of nitrogen. Before analysis, dry residues were dissolved in $1 \mathrm{~cm}^{3}$ of methanol. Twenty microlitres of the prepared mixture was analyzed by HPLC. The ERG separation was performed on a $3.9 \mathrm{~mm}$ Nova Pak C-18, $4 \mathrm{~mm}$ column with methanol:acetonitrile $(90: 10, \mathrm{v} / \mathrm{v})$ as the mobile phase at a flow rate of $1.0 \mathrm{~cm}^{3} / \mathrm{min}$. ERG was detected with a Waters 2996 Photodiode Array Detector (Waters Division of Millipore, Milford, MA, USA) set at $282 \mathrm{~nm}$. The presence of ERG was confirmed by a comparison of retention times with the external standard and by co-injection of every 
tenth sample with an ERG standard. The detection limit was $10 \mathrm{ng} / \mathrm{g}$.

\section{Zearalenone (ZEA)}

Plant material ( $5 \mathrm{~g}$ ) was homogenized for 3 min with $5 \mathrm{~cm}^{3}$ of acetonitrile:water $(90: 10, \mathrm{v} / \mathrm{v})$ solution. ZEA was extracted and purified on a Zearala Test column (Vicam, Milford, CT, USA) according to a previously described procedure (Goliński et al. 2010). The elute was evaporated to dryness at $40{ }^{\circ} \mathrm{C}$ under a stream of nitrogen. The dry residue was stored at $-20^{\circ} \mathrm{C}$ until HPLC analysis. Extracts were dissolved in a $500 \mathrm{~cm}^{3}$ mixture of acetonitrile:methanol:water $(70: 20: 10, \mathrm{v} / \mathrm{v} / \mathrm{v})$, homogenized in an ultrasonic bath (Ultron, type U-505, Dywity, Poland), filtered through a syringe filter of $0.2 \mu \mathrm{m}$ mesh size and transferred to the chromatographic column. The chromatographic system used in the study consisted of a Waters 2695 high-performance liquid chromatograph (Waters, Milford, CT, USA) with Waters 2475 Multi $\lambda$ Fluorescence Detector $\left(\lambda_{\mathrm{ex}}=274 \mathrm{~nm}\right.$, $\lambda_{\mathrm{em}}=440 \mathrm{~nm}$ ) and Waters 2996 Photodiode Array Detector and a Nova Pak C-18 column $(150 \times 3.9 \mathrm{~mm})$. Data were processed using Empower 1 software (Waters, Milford, CT, USA). Quantification of ZEA was performed by measuring the peak areas at the retention time according to the relevant calibration curve. A Photodiode Array Detector (PDA) was used to confirm the presence of ZEA based on the characteristic spectra of this compound. The limit of detection was $1.0 \mathrm{ng} / \mathrm{g}$.

\section{Trichothecenes}

Group B trichothecenes were extracted from plant material according to Perkowski et al. (2003). Type B trichothecenes (deoxynivalenol (DON), 3-acetyldeoxynivalenol (3-AcDON), 15-acetyldeoxynivalenol (15-AcDON), nivalenol (NIV), and fusarenon X (FUS-X)) were analyzed as trimethylsilyl derivatives using an external standard. Trimethylsilyl derivatives were obtained through the reaction with $100 \mu \mathrm{l}$ of trimethylsilyl imidazole and trimethylchlorosilane (100:1, v/v) mixture and run in a $10 \mathrm{~cm}^{3}$ vial at room temperature for $20 \mathrm{~min}$. Chromatographic separation and the analysis of group B trichothecenes were carried out using a gas chromatograph (Varian 450-GC) coupled with a mass detector (Varian 320-MS). The apparatus was equipped with an autosampler (CP-8400) and a capillary column (Varian SLB-5MS, $0.25 \mathrm{~mm} \times 30 \mathrm{~m}$ ). Samples of $1 \mu \mathrm{l}$ were injected into the injector chamber at $280{ }^{\circ} \mathrm{C}$ without stream division at the separator temperature of $290{ }^{\circ} \mathrm{C}$. The total time of analysis was $24.47 \mathrm{~min}$. Multiple reaction monitoring (MRM) was carried out for trichothecenes, and the retention times for the above toxins (DON, FUS-X, 3-AcDON, 15-AcDON, and NIV) were 13.16, $14.35,14.42,14.59$, and $14.72 \mathrm{~min}$, respectively. The flow rate for helium was $0.7 \mathrm{~cm}^{3} / \mathrm{min}$. The results were subjected to processing in the Varian MS Workstation ver. 6.9.2 software. The limit of detection for each analyzed mycotoxin (DON, 3- and 15-AcDON, NIV, and FUS-X) was $1 \mathrm{ng} / \mathrm{g}$.

\section{Statistical analysis}

The presented results are the means ( \pm standard deviation) of three replicate trials. The effect of EOs on the reduction of ergosterol, zearalenone, and group B trichothecenes was examined by multivariate analysis of variance (ANOVA). Analyses were carried out using STATISTICA for Windows version 10 .

\section{Results}

\section{Inhibitory effect of EOs on Fusarium growth}

Conducted laboratory trials demonstrated the antifungal properties of tested EOs. The results concerning growth inhibition of Fusarium isolates tested by diffusion assay are presented in Fig. 1. The highest antifungal activity was demonstrated by cinnamon, oregano, and palmarosa EOs. Spearmint, fennel, rosewood, and orange EOs showed similar and much lower efficacy in the inhibition of tested fungi. It is worth noting that the indicator microorganisms chosen for the study demonstrated different susceptibilities to different EOs. F. culmorum exhibited higher sensitivity to the oregano, cinnamon and verbena EOs, while $F$. graminearum was more susceptible to the oregano and cinnamon EOs. Differences in the sensitivity of the tested fungi to EOs were observed only for fennel, spearmint and verbena EOs.

The antifungal effect of each tested EO on the phytopathogenic fungi isolates was expressed in MIC values (Table 1). The oregano, cinnamon, palmarosa, and verbena EOs showed the highest activity, which was in line with the results obtained by the diffusion method. However, considering the sensitivity of the tested fungi, differences between the methods were observed. F. graminearum had higher sensitivity to a higher number of EOs (spearmint, rose wood, orange, and palmarosa), while the other oils showed the same activity against both tested fungi. However, it could be noted that the differences in MIC values were sometimes very small; therefore, they were probably not observed in the diffusion method (for example, the MIC difference between rosewood and palmarosa EOs).

\section{Effect of EOs on the growth and mycotoxin production of the Fusarium species}

After incubation of the grain samples with added EOs inoculated with Fusarium cultures, changes in the growth of $F$. graminearum and $F$. culmorum mycelium in relation 


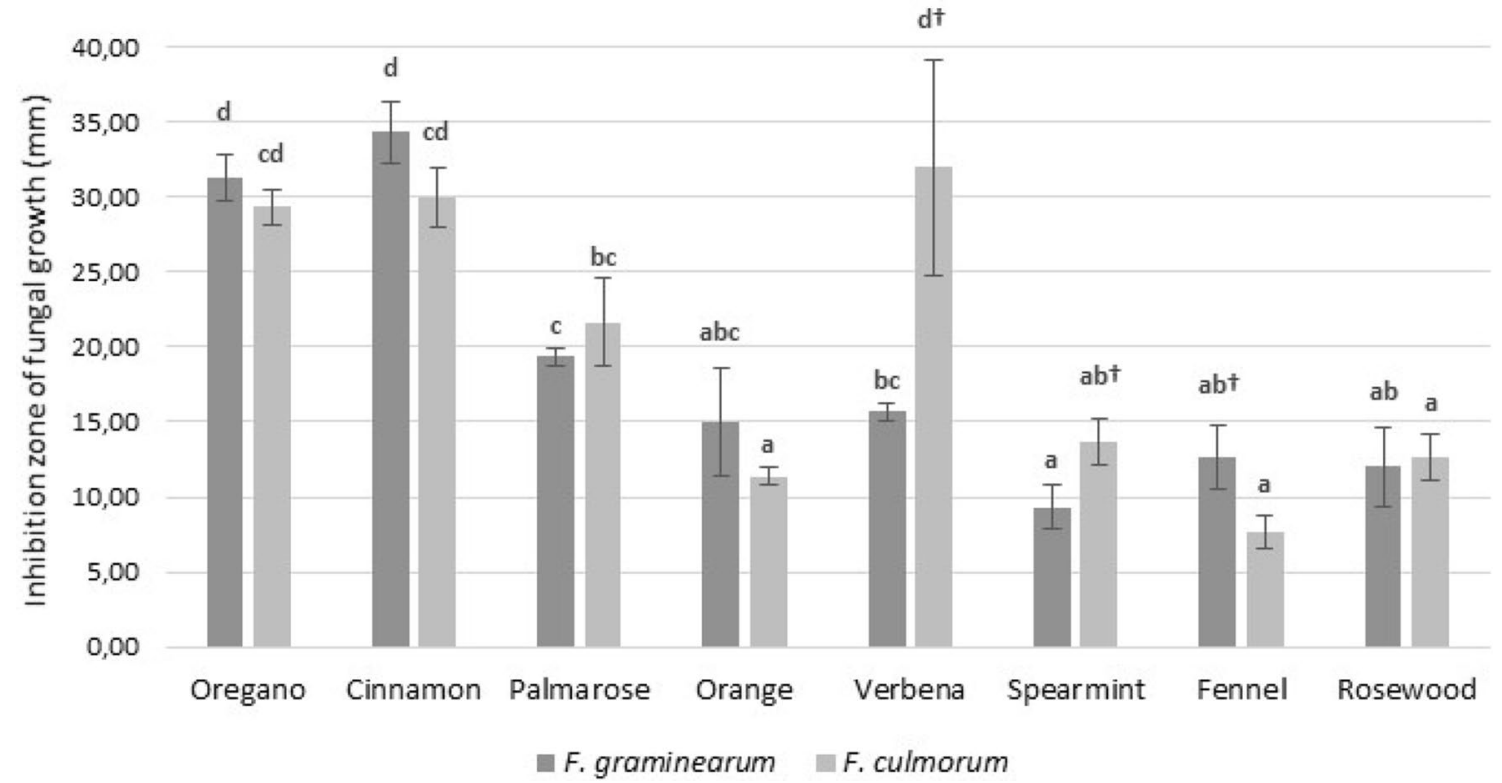

Fig. 1 The effect of essential oils on the growth of Fusarium strains. *Average with different letters (a-d) for each fungi are significantly different at the $p<0.05$.**Average with different symbols $(\dagger)$ for each essential oils are significantly different at the $p<0.05$

Table 1 Minimal inhibitory concentration (MIC) value of essential oils

\begin{tabular}{lll}
\hline Essential oils & \multicolumn{2}{l}{$\begin{array}{l}\text { Minimal inhibitory concentration of EOs } \\
\left(\mu \mathrm{l} / \mathrm{cm}^{3}\right)\end{array}$} \\
\cline { 2 - 3 } & F. graminearum & F. culmorum \\
\hline Oregano & $<0.8$ & $<0.8$ \\
Cinnamon & $<0.8$ & $<0.8$ \\
Palmarosa & 0.8 & 3.1 \\
Orange & 12.5 & $>100$ \\
Spearmint & 12.5 & 50 \\
Verbena & $<0.8$ & $<0.8$ \\
Fennel & $<0.8$ & $>100$ \\
Rosewood & 6.2 & 12.5 \\
\hline
\end{tabular}

to control trials were observed (Figs. 2, 3). The differences in the growth of tested fungi were visible. All EOs reduced the growth of mycelium; however, the weakest effect on the growth inhibition was demonstrated by orange oil. Further, the concentration of ergosterol and Fusarium mycotoxins was determined by HPLC analysis to confirm the effect of EOs on fungal growth (Tables 2, 3, 4, 5).

\section{The effect of EOs on the ergosterol concentration in wheat samples}

Analysis of ergosterol (ERG) concentration allowed us to estimate the degree of growth inhibition of the two species, $F$. graminearum and $F$. culmorum, in wheat grain after the addition of the EO solutions. The percentage reduction was also calculated in comparison with the control trials (Table 2). The results showed that the concentration of ergosterol was significantly decreased in samples with the addition of tested EOs. An exception was observed in orange EO trials, where the reduction in ERG concentration amounted to $90.99 \%$ and $68.13 \%$ in $F$. graminearum and $F$. culmorum samples, respectively.

\section{The effect of EOs on the zearalenone concentration in wheat samples}

The amount of zearalenone (ZEA) in wheat samples inoculated with Fusarium isolates was significantly reduced by EO activity/addition (Table 3). Very low concentrations of ZEA $(0.00-5.33 \mu \mathrm{g} / \mathrm{g})$ were observed in $F$. graminearum samples treated with EOs. ZEA reduction was at $99.57-100 \%$, with the lowest efficiency in samples with orange oil. The addition of EOs to the samples inoculated with $F$. culmorum also resulted in a significant reduction in the ZEA amount. The degree of toxin reduction reached $99.08-99.99 \%$ with the exception of the sample with orange oil, where the reduction amount was $68.33 \%$.

\section{The effect on group B trichothecene concentration in wheat samples}

GC-MS/MS analysis led to the identification of group B trichothecenes in the analyzed wheat grain samples. In the 


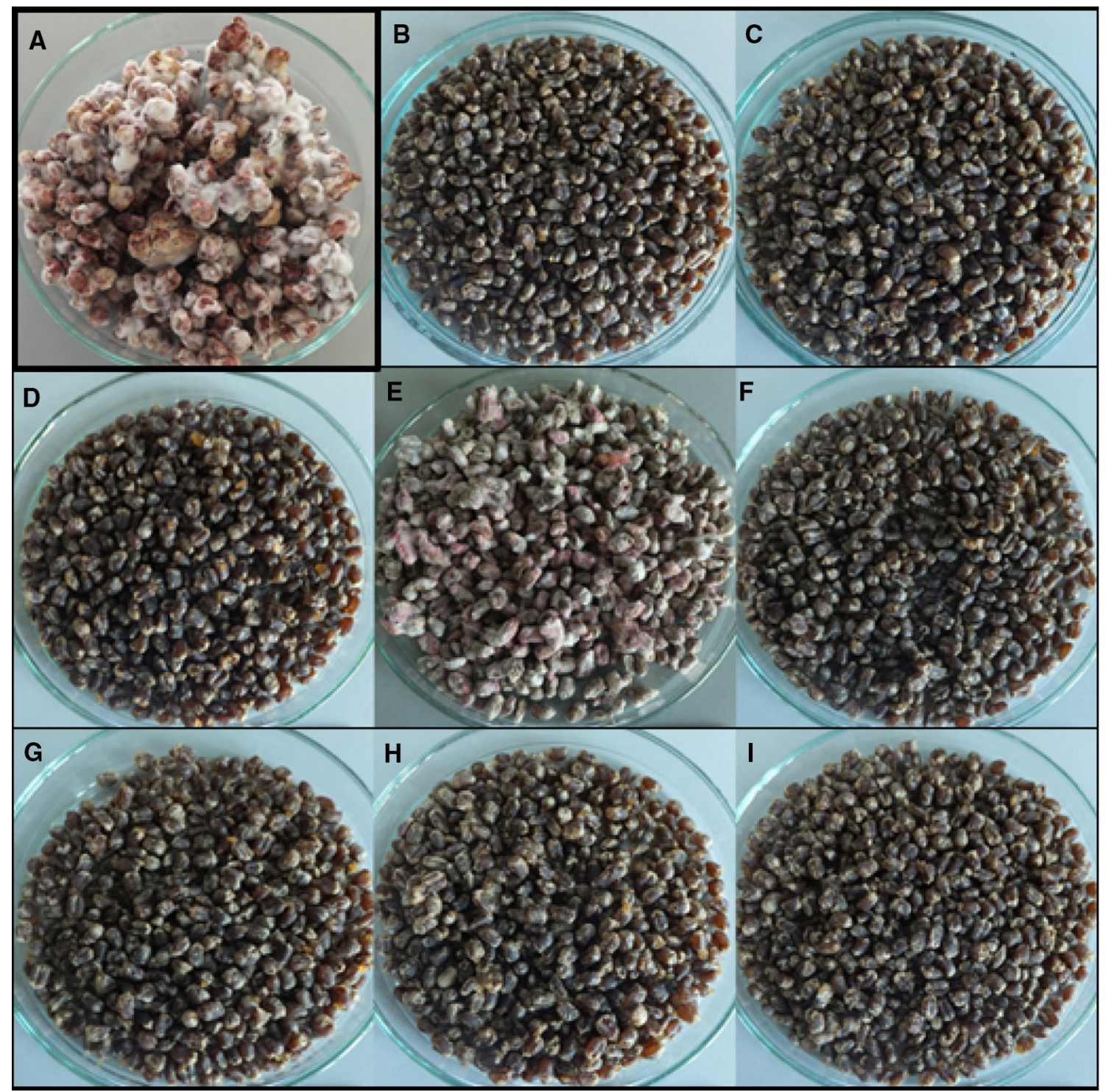

Fig. 2 Effect of the application of EOs on the growth of $F$. graminearum on the wheat grain $(\mathbf{a}-$ control, $\mathbf{b}-$ oregano oil, $\mathbf{c}-$ cinnamon oil, $\mathbf{d}-$ palmarosa oil, $\mathbf{e}$ - orange oil, $\mathbf{f}$ - verbena oil, $\mathbf{g}$ - spearmint oil, $\mathbf{h}$-fennel oil, $\mathbf{i}$-rosewood oil)

control group inoculated with $F$. graminearum, DON, FUS$\mathrm{X}, 3-\mathrm{AcDON}$, and 15-AcDON were identified, while NIV was not detected (Table 4). The highest concentration was recorded for DON $(13.23 \mu \mathrm{g} / \mathrm{g})$, while the amount of other identified compounds was very low. The addition of EOs resulted in a significant reduction in identified toxin concentrations. The percentage reduction degree reached from 96.33 to $100 \%$ depending on the EO used and the mycotoxin. Similarly, inoculation with $F$. culmorum resulted in the formation of trichothecenes in wheat grain (Table 5). DON, FUS-X, and 3-AcDON were detected, while there were no traces of 15-AcDON and NIV. F. graminearum produced the largest amounts of DON $(5.47 \mu \mathrm{g} / \mathrm{g})$ in comparison to other identified mycotoxins. The addition of EOs significantly reduced the concentrations of these compounds, and the degree of reduction varied from 94.51 to $100 \%$.

\section{Discussion}

In recent decades, there has been an increasing demand to reduce the use of chemical substances in the plant protection and food industries; therefore, natural compounds such as EOs have been intensively studied. The present study focused on the effect of some EOs on the growth and mycotoxin production of Fusarium species based on in vitro experiments, including disc diffusion assays, MIC determination and model experiments in wheat grain. All tested 


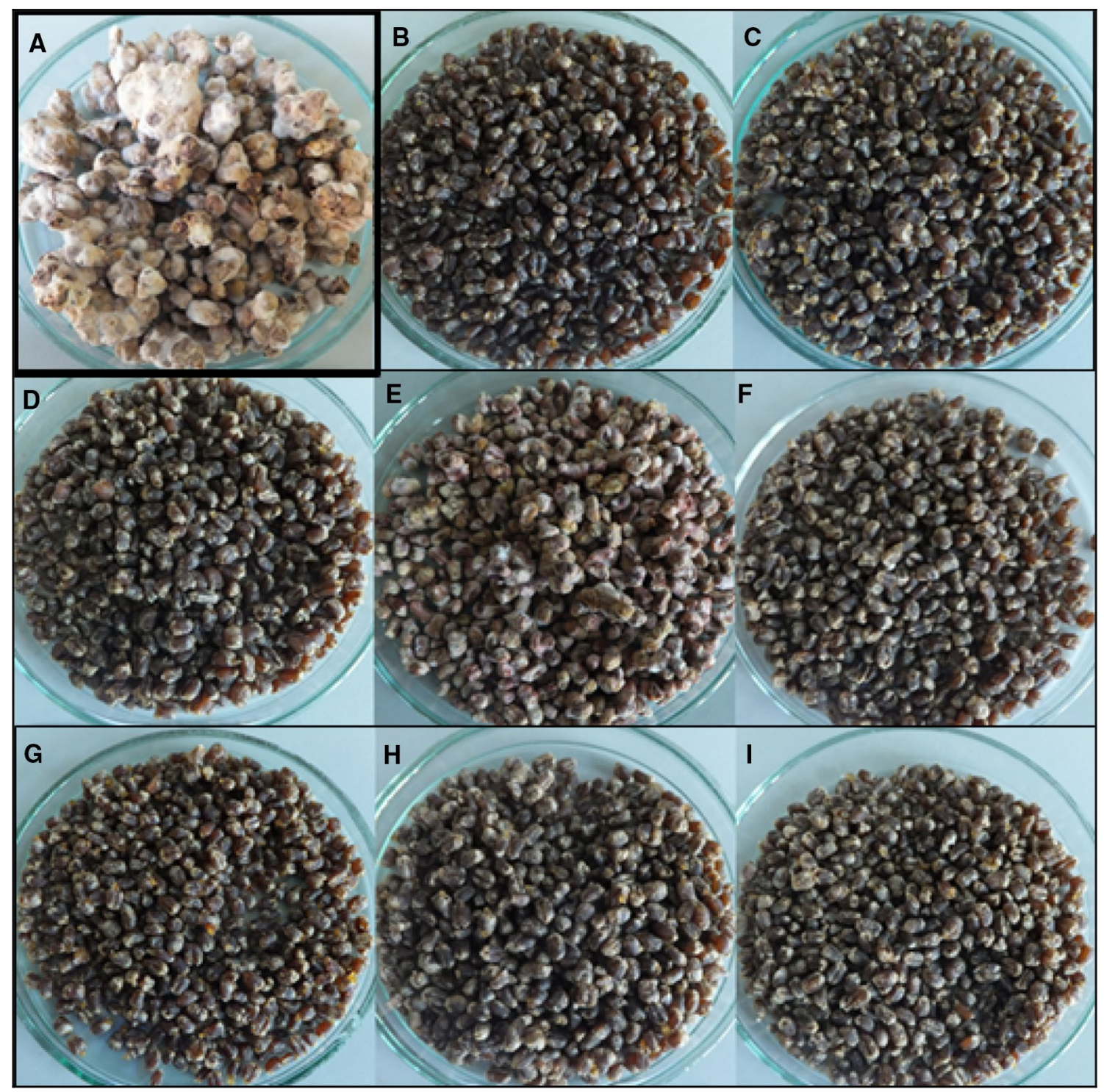

Fig. 3 Effect of the application of EOs on the growth of $F$. culmorum on the wheat grain (a-control, b-oregano oil, $\mathbf{c}-$ cinnamon oil, $\mathbf{d}-$ palmarosa oil, e—orange oil, $\mathbf{f}$ - verbena oil, $\mathbf{g}$ - spearmint oil, $\mathbf{h}$-fennel oil, $\mathbf{i}$ - rosewood oil)

EOs inhibited the growth of Fusarium strains; however, the degree of inhibition and MIC value depended on the examined EO and fungal strain. These results are in line with the observations of other authors. Seseni et al. (2015) examined the effect of different EOs on growth inhibition of Fusarium under in vitro conditions. The antifungal activity depended on the kind of EO and its concentration. Of the ten examined EOs, clove, thyme and lemongrass demonstrated the highest activity, completely inhibiting the growth of the four tested Fusarium species (F. oxysporum and three strains of $F$. circinatum) at a concentration of $1000 \mu \mathrm{l} / \mathrm{l}$. The lowest reduction was observed for a combination of mandarin, grapefruit, and orange EOs, which caused a reduction in mycelium growth up to $25 \%$. EOs with the highest activity were also tested to determine MIC for the fungi. MIC values were differentiated depending on the EO and the Fusarium species. The lowest MIC value was determined for lemongrass oil, which inhibited the growth of $F$. oxysporum and one strain of $F$. circinatum at concentrations of $300 \mu \mathrm{l} / 1$ and $400 \mu \mathrm{l} / \mathrm{l}$, respectively. The MIC of clove and thyme oils were $400-500 \mu \mathrm{l} / \mathrm{l}$ for both tested species. Matusinsky et al. (2015) tested five different EOs for their growth inhibition capabilities on Fusarium culmorum strains under in vitro conditions. The addition of $1 \mu \mathrm{l} / \mathrm{cm}^{3}$ of Thymus vulgaris essential oil (EO) resulted in complete growth inhibition of these strains. After the addition of oils from Pimpinella anisum, Pelargonium odoratissimum, and Foeniculum vulgare, total growth inhibition with a dose of $5 \mu \mathrm{l} / \mathrm{cm}^{3}$ was obtained, while in the case of 
Table 2 Ergosterol (ERG) content $[\mu \mathrm{g} / \mathrm{g}]$ and percentage of reduction [\%] in wheat samples treated with EOs (20\% concentration) after inoculation with Fusarium species

\begin{tabular}{lccccc}
\hline EOs & \multicolumn{4}{l}{ ERG content $[\mu \mathrm{g} / \mathrm{g}]$ and percentage of reduction $[\%]$} \\
\cline { 2 - 3 } & \multicolumn{2}{l}{ F. graminearum } & & & F. culmorum \\
\cline { 2 - 3 } & $\mu \mathrm{gg} / \mathrm{g}$ & & $\mu \mathrm{g} / \mathrm{g}$ & $\%$ \\
\hline Control (without EOs) & $2805.87^{\mathrm{a}} \pm 744.49$ & - & & $3572.26^{\mathrm{a}} \pm 493.60$ & - \\
Oregano & $0.83^{\mathrm{b}} \pm 0.05$ & 99.97 & & $0.54^{\mathrm{b}} \pm 0.06$ & 99.98 \\
Cinnamon & $2.95^{\mathrm{b}} \pm 0.60$ & 99.89 & & $6.80^{\mathrm{b}} \pm 8.49$ & 99.81 \\
Palmarosa & $0.76^{\mathrm{b}} \pm 0.25$ & 99.97 & & $0.87^{\mathrm{b}} \pm 0.06$ & 99.98 \\
Orange & $252.80^{\mathrm{b}} \pm 86.05$ & 90.99 & & $1138.57^{\mathrm{b}} \pm 1359.37$ & 68.13 \\
Spearmint & $0.51^{\mathrm{b}} \pm 0.09$ & 99.98 & & $0.62^{\mathrm{b}} \pm 0.28$ & 99.98 \\
Verbena & $0.60^{\mathrm{b}} \pm 0.30$ & 99.98 & & $0.63^{\mathrm{b}} \pm 0.32$ & 99.98 \\
Fennel & $0.39^{\mathrm{b}} \pm 0.02$ & 99.99 & & $0.71^{\mathrm{b}} \pm 0.13$ & 99.98 \\
Rosewood & $0.68^{\mathrm{b}} \pm 0.10$ & 99.98 & & $0.45^{\mathrm{b}} \pm 0.07$ & 99.99 \\
\hline
\end{tabular}

Data were analyzed by Tukey's test at $p<0.05$ (a, b-significantly different)
Table 3 Zearalenone (ZEA) content $[\mu \mathrm{g} / \mathrm{g}]$ and percentage of reduction [\%] in wheat samples treated with EOs (20\% concentration) after inoculation with Fusarium species

\begin{tabular}{|c|c|c|c|c|}
\hline \multirow[t]{3}{*}{ EOs } & \multicolumn{4}{|c|}{ ZEA content $[\mu \mathrm{g} / \mathrm{g}]$ and percentage of reduction [\%] } \\
\hline & \multicolumn{2}{|l|}{ F. graminearum } & \multicolumn{2}{|l|}{ F. culmorum } \\
\hline & $\mu \mathrm{g} / \mathrm{g}$ & $\%$ & $\mu \mathrm{g} / \mathrm{g}$ & $\%$ \\
\hline $\begin{array}{l}\text { Control (with- } \\
\text { out EOs) }\end{array}$ & $1244.71^{\mathrm{a}} \pm 231.84$ & - & $117.51^{\mathrm{a}} \pm 7.88$ & - \\
\hline Oregano & $\mathrm{nd}^{* \mathrm{~b}}$ & 100.00 & $1.08^{\mathrm{b}} \pm 0.44$ & 99.08 \\
\hline Cinnamon & $0.01^{\mathrm{b}} \pm 0.01$ & 100.00 & $0.06^{\mathrm{b}} \pm 0.02$ & 99.95 \\
\hline Palmarosa & $\mathrm{nd}^{\mathrm{b}}$ & 100.00 & $0.03^{\mathrm{b}} \pm 0.01$ & 99.98 \\
\hline Orange & $5.33^{\mathrm{b}} \pm 0.36$ & 99.57 & $37.21^{b} \pm 56.17$ & 68.33 \\
\hline Spearmint & $\mathrm{nd}^{\mathrm{b}}$ & 100.00 & $0.34^{\mathrm{b}} \pm 0.01$ & 99.71 \\
\hline Verbena & $\mathrm{nd}^{\mathrm{b}}$ & 100.00 & $0.03^{\mathrm{b}} \pm 0.01$ & 99.97 \\
\hline Fennel & $0.01^{\mathrm{b}} \pm 0.00$ & 100.00 & $0.02^{\mathrm{b}} \pm 0.01$ & 99.98 \\
\hline Rosewood & $\mathrm{nd}^{\mathrm{b}}$ & 100.00 & $0.01^{\mathrm{b}} \pm 0.01$ & 99.99 \\
\hline
\end{tabular}

Data were analyzed by Tukey's test at $p<0.05$ (a, b-significantly different)

*nd—not detected

Rosmarinus officinalis EO, even a dose of $10 \mu \mathrm{l} / \mathrm{cm}^{3}$ was not enough to completely inhibit the two strains of $\mathrm{F}$. $\mathrm{cul}$ morum. Kalagatur et al. (2015) showed that the EO of Ocimum sanctum $\mathrm{L}$. inhibited the growth of $F$. graminearum and the minimum inhibitory concentration (MIC) was $1250 \mu \mathrm{g} /$ $\mathrm{cm}^{3}$. Naeini et al. (2010) tested the antifungal activity of EOs of five medicinal plants (Zataria multiflora, Heracleum persicum, Pinaceae, Cuminum cyminum, and Foeniculum vulgare) against different Fusarium isolates and stated that the MIC values were very differentiated. Depending on the fungal strain and tested EO, the MIC ranged from 63 to $4500 \mu \mathrm{g} / \mathrm{cm}^{3}$. The differences between EOs and the sensitivity of particular Fusarium species were also observed by Zabka et al. (2009). The authors observed total inhibition of
F. oxysporum and $F$. verticillioides with EO obtained from Pimenta dioica (L.) and inhibition exceeded $98 \%$ with EO obtained from Thymus vulgaris at a concentration of $1 \mu \mathrm{l} /$ $\mathrm{cm}^{3}$, while other tested EOs demonstrated weaker antifungal activity at this concentration. The MIC values determined for the five EOs with the highest antifungal properties were established at a level of $0.5-6.7 \mu \mathrm{l} / \mathrm{cm}^{3}$, depending on the tested EO and Fusarium strain, which were in agreement with the results obtained in the presented work.

The inhibition of $F$. graminearum and $F$. culmorum growth by tested EOs was confirmed by HPLC analysis of ergosterol content in wheat samples infected by Fusarium strains. Ergosterol is a characteristic component of the fungal cell wall, while bacterial, plant and animal cells are devoid of this compound (Weete and Gandhi 1996; Weete et al. 2010). Therefore, ergosterol is considered to be a suitable marker for estimating fungal biomass in different matrices, such as plant material (Richardson and Logendra 1997; Gutarowska and Zakowska 2010; Porep et al. 2014), grass seeds (Richardson and Logendra 1997), soil (Montgomery et al. 2000; Ruzicka et al. 2000), and grains (Saxena et al. 2001; Olsson et al. 2002; Pietri et al. 2004). YamamotoRibeiro et al. (2013) showed that EO obtained from Zingiber officinale inhibited the growth of Fusarium verticillioides. The concentrations of ergosterol and fumonisin $\mathrm{B}_{1}$ were reduced. Additionally, components of EOs are known to inhibit fungal growth. Gao et al. (2016) revealed that thymol inhibited the growth of $F$. graminearum, which was documented by the results of ergosterol analysis. In comparison with the control, the addition of thymol resulted in a reduction of ERG by 25, 50, and 55\% for doses of 25, 50, and $100 \mu \mathrm{g} / \mathrm{cm}^{3}$, respectively. In the present work, a significant reduction in ergosterol content was observed in all wheat samples treated with EOs; however, orange oil was the least effective. The literature data suggest that antifungal compounds, including EOs, may inhibit the cell growth of fungi 
Table 4 Trichothecenes (DON, NIV, 3-AcDON, 15-AcDON, FUS-X) content $[\mu \mathrm{g} / \mathrm{g}]$ and percentage of reduction [\%] in wheat samples treated with EOs (20\% concentration) after inoculation with Fusarium graminearum

\begin{tabular}{lccccc}
\hline \multicolumn{5}{l}{ Trichothecenes content $[\mu \mathrm{g} / \mathrm{g}]$ (percentage of reduction-\%) } \\
\hline EOs & $\mathrm{DON}$ & $\mathrm{NIV}$ & 3 -AcDON & $15-\mathrm{AcDON}$ & $\mathrm{FUS}-\mathrm{X}$ \\
\hline Control (without EOs) & $13.23^{\mathrm{a}} \pm 13.93$ & $\mathrm{nd}^{* \mathrm{a}}$ & $1.54^{\mathrm{a}} \pm 0.07$ & $1.57^{\mathrm{a}} \pm 0.02$ & $1.26^{\mathrm{a}} \pm 0.07$ \\
Oregano & $0.04^{\mathrm{a}} \pm 0.00(99.70) \mathrm{nd}^{\mathrm{a}}$ & $0.03^{\mathrm{b}} \pm 0.02$ & $0.03^{\mathrm{b}} \pm 0.03(98.09)$ & $0.04^{\mathrm{b}} \pm 0.00$ \\
& & - & $(98.05)$ & & $(96.82)$ \\
Cinnamon & $0.04^{\mathrm{a}} \pm 0.00(99.70) \mathrm{nd}^{\mathrm{a}}$ & $0.04^{\mathrm{b}} \pm 0.00$ & $\mathrm{nd}^{\mathrm{b}}(100.00)$ & $0.04^{\mathrm{b}} \pm 0.00$ \\
& & - & $(97.40)$ & & $(96.82)$ \\
Palmarosa & $0.05^{\mathrm{a}} \pm 0.00(99.62) \mathrm{nd}^{\mathrm{a}}$ & $0.03^{\mathrm{b}} \pm 0.03$ & $0.05^{\mathrm{b}} \pm 0.00(96.82)$ & $0.03^{\mathrm{b}} \pm 0.02$ \\
& & - & $(98.05)$ & & $(97.62)$ \\
Orange & $0.05^{\mathrm{a}} \pm 0.00(99.62) \mathrm{nd}^{\mathrm{a}}$ & $0.03^{\mathrm{b}} \pm 0.03$ & $0.02^{\mathrm{b}} \pm 0.03(98.73)$ & $0.04^{\mathrm{b}} \pm 0.00$ \\
& & - & $(98.05)$ & & $(96.82)$ \\
Spearmint & $0.05^{\mathrm{a}} \pm 0.00(99.62) \mathrm{nd}^{\mathrm{a}}$ & $0.05^{\mathrm{b}} \pm 0.00$ & $\mathrm{nd}^{\mathrm{b}}(100.00)$ & $0.04^{\mathrm{b}} \pm 0.00$ \\
& & - & $(96.75)$ & & $(96.82)$ \\
Verbena & $0.04^{\mathrm{a}} \pm 0.00(99.70) \mathrm{nd}^{\mathrm{a}}$ & $0.05^{\mathrm{b}} \pm 0.00$ & $\mathrm{nd}^{\mathrm{b}}(100.00)$ & $0.05^{\mathrm{b}} \pm 0.00$ \\
& & - & $(96.75)$ & & $(96.03)$ \\
Fennel & $0.05^{\mathrm{a}} \pm 0.00$ & $\mathrm{nd}^{\mathrm{a}}$ & $0.05^{\mathrm{b}} \pm 0.00$ & $\mathrm{nd}^{\mathrm{b}}(100.00)$ & $0.04^{\mathrm{b}} \pm 0.00$ \\
& $(99.62)$ & - & $(96.75)$ & & $(96.82)$ \\
Rosewood & $0.04^{\mathrm{a}} \pm 0.00$ & $\mathrm{nd}^{\mathrm{a}}$ & $0.04^{\mathrm{b}} \pm 0.00$ & $\mathrm{nd}^{\mathrm{b}}(100.00)$ & $0.02^{\mathrm{b}} \pm 0.03$ \\
& $(99.70)$ & - & $(97.40)$ & & $(98.41)$ \\
\hline
\end{tabular}

Data were analyzed by Tukey's test at $p<0.05$ (a, b-significantly different)

*nd-not detected

\begin{tabular}{llllll}
\hline \multicolumn{7}{l}{ Trichothecenes content $[\mu \mathrm{g} / \mathrm{g}]($ percentage of reduction-\%) } \\
\hline EOs & $\mathrm{DON}$ & $\mathrm{NIV}$ & $3-\mathrm{AcDON}$ & $15-\mathrm{AcDON}$ & $\mathrm{FUS}-\mathrm{X}$ \\
\hline Control (without EOs) & $5.47^{\mathrm{a}} \pm 1.78$ & $\mathrm{nd}^{\mathrm{a}}$ & $1.60^{\mathrm{a}} \pm 0.19$ & $\mathrm{nd}^{\mathrm{a}}$ & $0.83^{\mathrm{a}} \pm 0.73$ \\
Oregano & $0.04^{\mathrm{b}} \pm 0.00$ & $\mathrm{nd}^{\mathrm{a}}$ & $0.04^{\mathrm{b}} \pm 0.02$ & $\mathrm{nd}^{\mathrm{a}}$ & $0.04^{\mathrm{a}} \pm 0.00$ \\
& $(99.26)$ & - & $(97.50)$ & - & $(97.50)$ \\
Cinnamon & $0.04^{\mathrm{b}} \pm 0.01$ & $\mathrm{nd}^{\mathrm{a}}$ & $0.05^{\mathrm{b}} \pm 0.01$ & $\mathrm{nd}^{\mathrm{a}}$ & $0.04^{\mathrm{a}} \pm 0.01$ \\
& $(99.26)$ & - & $(96.88)$ & - & $(95.18)$ \\
Palmarosa & $0.05^{\mathrm{b}} \pm 0.01(99.26)$ & $\mathrm{nd}^{\mathrm{a}}$ & $0.04^{\mathrm{b}} \pm 0.01$ & $\mathrm{nd}^{\mathrm{a}}$ & $0.03^{\mathrm{a}} \pm 0.02$ \\
& & - & $(97.50)$ & - & $(96.39)$ \\
Orange & $0.04^{\mathrm{b}} \pm 0.02$ & $\mathrm{nd}^{\mathrm{a}}$ & $0.04^{\mathrm{b}} \pm 0.01$ & $\mathrm{nd}^{\mathrm{a}}$ & $0.02^{\mathrm{a}} \pm 0.02$ \\
& $(99.26)$ & - & $(97.50)$ & - & $(97.59)$ \\
Spearmint & $0.04^{\mathrm{b}} \pm 0.00$ & $\mathrm{nd}^{\mathrm{a}}$ & $0.04^{\mathrm{b}} \pm 0.00$ & $\mathrm{nd}^{\mathrm{a}}$ & $\mathrm{nd}$ \\
& $(99.26)$ & - & $(97.50)$ & - & $(100.00)$ \\
Verbena & $0.03^{\mathrm{b}} \pm 0.00$ & $\mathrm{nd}^{\mathrm{a}}$ & $\mathrm{nd}^{\mathrm{b}}$ & $\mathrm{nd}^{\mathrm{a}}$ & $0.04^{\mathrm{a}} \pm 0.00$ \\
& $(99.45)$ & - & $(100.00)$ & - & $(95.18)$ \\
Fennel & $0.03^{\mathrm{b}} \pm 0.00$ & $\mathrm{nd}^{\mathrm{a}}$ & $0.04^{\mathrm{b}} \pm 0.00$ & $\mathrm{nd}^{\mathrm{a}}$ & $0.03^{\mathrm{a}} \pm 0.00$ \\
& $(99.45)$ & - & $(97.50)$ & - & $(96.39)$ \\
Rosewood & $0.04^{\mathrm{b}} \pm 0.00$ & $\mathrm{nd}^{\mathrm{a}}$ & $0.05^{\mathrm{b}} \pm 0.00$ & $\mathrm{nd}^{\mathrm{a}}$ & $0.05^{\mathrm{a}} \pm 0.01$ \\
& $(99.26)$ & - & $(96.88)$ & - & $(93.98)$ \\
\hline
\end{tabular}

nd-not detected

Data were analyzed by Tukey's test at $p<0.05$ (a, b — significantly different)
Table 5 Trichothecenes (DON, NIV, 3-AcDON, 15-AcDON, FUS-X) content $[\mu \mathrm{g} / \mathrm{g}]$ and percentage of reduction [\%] in wheat samples treated with EOs (20\% concentration) after inoculation with Fusarium culmorum by interrupting ergosterol biosynthesis, which affects cell growth and proliferation (Ahmad et al. 2011). YamamotoRibeiro et al. (2013) determined the ergosterol content produced by $F$. verticillioides treated with different concentrations of ginger EO. Higher concentrations (4000-5000 $\mu \mathrm{g} /$ $\mathrm{cm}^{3}$ ) of ginger EO effectively inhibited ergosterol production, while lower concentrations $\left(500-3000 \mu \mathrm{g} / \mathrm{cm}^{3}\right)$ caused oscillations in ergosterol production. The authors also observed an increase in ERG biosynthesis at $1000 \mu \mathrm{g} / \mathrm{cm}^{3}$. Similar oscillations in ergosterol production were observed by Dambolena et al. (2010) and Lucini et al. (2006).

Although ergosterol is a good marker of fungal growth, it cannot be used as a suitable indicator of mycotoxin content. Stanisz et al. (2015) stated that even a low content of 
ergosterol did not indicate a low level of mycotoxins. This could be because the death of fungi causes a decrease in ergosterol content, but the amount of mycotoxins usually stays at a constant level. Moreover, mycotoxins are not produced by every fungal strain. In the present work, an almost total reduction in zearalenone and group B trichothecenes was observed in the presence of the majority of EOs, so it was difficult to state the correlation between ergosterol content and the concentration of mycotoxins. Only in the case of orange oil was the reduction of ergosterol and zearalenone content lower in comparison to the reductions with other EOs, and the reduction in ZEA content was proportionally lower than that in samples treated with other EOs.

The effect of EOs on mycotoxin biosynthesis has been observed by many authors on both synthetic media and cereal matrices. Yamamoto-Ribeiro et al. (2013) observed significant inhibition of the production of fumonisin B1 by $F$. verticillioides in liquid medium at a concentration of $4000 \mu \mathrm{g} / \mathrm{cm}^{3}$ and complete inhibition at a concentration of $5000 \mu \mathrm{g} / \mathrm{cm}^{3}$. Kalagatur et al. (2015) studied the effect of the EO from Ocimum sanctum L. on the growth and ZEA production of $F$. graminearum in corn grain. The concentration of ZEA significantly decreased with increasing EO concentration. Moreover, at concentrations 1500 and $2000 \mu \mathrm{g} / \mathrm{g}$ of $\mathrm{EO}$, the toxin content was below the limit of detection. The results confirm that EOs may strongly decrease the level of mycotoxins, and the decrease depends on the kind of EO and its concentration. Some authors indicate that the effect of EOs on the production of mycotoxins by Fusarium spp. or other fungi is affected by the treatment conditions, such as the temperature and moisture content of the grains. Temperature, dose and type of EOs influenced fumonisin production by F. proliferatum, as described by Velluti et al. (2004). In the work of Sumalan et al. (2013), decreased content of DON and $\mathrm{FB}_{1}$ was observed under constant conditions of water activity and temperature.

It is worth noting that EOs may also degrade mycotoxins, which may also cause a reduction in their concentration in different matrices. Xing et al. (2014) tested some EOs for the reduction of mycotoxin concentration under in vitro conditions. The best properties were exhibited by cinnamon and lemon oils, which resulted in the reduction of $\mathrm{FB}_{1}$ by 66.65 and $53.19 \%$, respectively. Moreover, the influence of incubation time and temperature on the reduction of mycotoxin by cinnamon oil was examined. The results showed that the degree of reduction of mycotoxin increased with incubation time, and after reaching $120 \mathrm{~h}$, a $72.92 \%$ reduction was achieved. Additionally, with the increase in the incubation temperature, an increase in the degree of reduction of $\mathrm{FB}_{1}$ was observed. Perczak et al. (2016) revealed that EOs reduce zearalenone concentration under in vitro conditions and that the amount of reduction depends on the time of incubation, concentration of the toxin and $\mathrm{EO}$, and $\mathrm{pH}$ and temperature conditions. The highest reduction level was reached after $72 \mathrm{~h}$ in the case of lemon oil (46.46\%). Doubling the dose of EOs (from 100 to $200 \mu \mathrm{l} / \mathrm{cm}^{3}$ ) resulted in significant differences in the reduction of mycotoxin using white grapefruit EO (from 15.15 to $70.81 \%$ ), while the addition of lemon oil caused a decrease in the reduction (from 66.56 to $26.97 \%$ ). Increasing the dose of the toxin from 0.5 to $5.0 \mu \mathrm{g} / \mathrm{cm}^{3}$ resulted in the highest degree of reduction for palmarosa oil (97.89-99.29\% for three different $\mathrm{pH}$ values) and lemon oil (87.93-97.28\%). The use of different $\mathrm{pH}$ values did not result in significant differences in the values of reduced concentrations of the ZEA at an initial dose of $0.5 \mu \mathrm{g} / \mathrm{cm}^{3}$, but using a dose of $5 \mu \mathrm{g} / \mathrm{cm}^{3}$, there were differences-the addition of eucalyptus oil resulted in an increase in the degree of reduction at the level of 59.56-91.74\%, with increasing $\mathrm{pH}$.

\section{Conclusions}

Fusarium species may cause severe plant diseases and produce mycotoxins, which have a serious impact on human and animal health. The EOs inhibited the growth of fungi and reduced mycotoxin production. The results suggest the possibility of EO application as an alternative to chemical pesticides, for example, as a seed treatment intended for sowing, which may contribute to increased resistance of plants to Fusarium. Consequently, EOs may increase food and feed safety in the food chain. The vast variety of oils offers many possibilities for both application and further research.

\section{Compliance with ethical standards}

Conflict of interest The authors declare no conflict of interest.

Open Access This article is distributed under the terms of the Creative Commons Attribution 4.0 International License (http://creativeco mmons.org/licenses/by/4.0/), which permits unrestricted use, distribution, and reproduction in any medium, provided you give appropriate credit to the original author(s) and the source, provide a link to the Creative Commons license, and indicate if changes were made.

\section{References}

Ahmad A, Khan A, Kumar P, Bhatt RP, Manzoor N (2011) Antifungal activity of Coriaria nepalensis essential oil by disrupting ergosterol biosynthesis and membrane integrity against Candida. Yeast 28(8):611-617. https://doi.org/10.1002/yea. 1890

Ahmad A, Khan A, Manzoor N (2013) Reversal of efflux mediated antifungal resistance underlies synergistic activity of two monoterpenes with fluconazole. Eur J Pharm Sci 48:80-86. https ://doi.org/10.1016/j.ejps.2012.09.016 
Assunção R, Silva MJ, Alvito P (2016) Challenges in risk assessment of multiple mycotoxins in food. World Mycotoxin J 9:791-811. https://doi.org/10.3920/WMJ2016.2039

Avanço GB, Ferreira FD, Bomfim NS, de Souza Rodrigues dos Santos PA, Peralta RM, Brugnari T, Mallmann CA, de Abreu Filho BA, Mikcha JMG, Machinski M (2017) Curcuma longa L. essential oil composition, antioxidant effect, and effect on Fusarium verticillioides and fumonisin production. Food Control 73:806-813. https ://doi.org/10.1016/j.foodcont.2016.09.032

Bakkali F, Averbeck S, Averbeck D, Idaomar MM (2008) Biological effects of essential oils-a review. Food Chem Toxicol 46:446475. https://doi.org/10.1016/j.fct.2007.09.106

Boire N, Zhang S, Khuvis J, Lee R, Rivers J, Crandall P, Keel MK, Parrish N (2016) Potent inhibition of Pseudogymnoascus destructans, the causative agent of white-nose syndrome in bats, by cold-pressed, terpeneless, Valencia orange oil. PLoS One 11(2):e0148473. https://doi.org/10.1371/journal.pone.0148473

Boukaew S, Prasertsan P, Sattayasamitsathit S (2017) Evaluation of antifungal activity of essential oils against aflatoxigenic Aspergillus flavus and their allelopathic activity from fumigation to protect maize seeds during storage. Ind Crops Prod 97:558-566. https://doi.org/10.1016/j.indcrop.2017.01.005

Bozik M, Císarová M, Tancinová D, Kourimská L, Hleba L, Kloucek P (2017) Selected essential oil vapours inhibit growth of Aspergillus spp. in oats with improved consumer acceptability. Ind Crops Prod 98:146-152. https://doi.org/10.1016/j.inder op.2016.11.044

Bozin B, Mimica-Dukic N, Simin N, Anackov G (2006) Characterization of the volatile composition of essential oils of some Lamiaceae species and the antimicrobial and antioxidant activities of the entire oils. J Agr Food Chem 54:1822-1828. https://doi. org/10.1021/jf051922u

Calo JR, Crandall PG, O’Bryan CA, Ricke SC (2015) Essential oils as antimicrobials in food systems-a review. Food Control 54:111119. https://doi.org/10.1016/j.foodcont.2014.12.040

Chen Y, Zeng H, Tian J, Ban X, Ma B, Wang Y (2013) Antifungal mechanism of essential oil from Anethum graveolens seeds against Candida albicans. J Med Microbiol 62:1175-1183. https://doi. org/10.1099/jmm.0.055467-0

Covarelli L, Beccari G, Prodi A, Generotti S, Etruschi F, Juan C, Ferrer E, Mañes J (2015) Fusarium species, chemotype characterisation and trichothecene contamination of durum and soft wheat in an area of central Italy. J Sci Food Agric 95:540-551. https://doi. org/10.1002/jsfa.6772

da Cruz Cabral L, Pinto VF, Patriarca A (2013) Application of plant derived compounds to control fungal spoilage and mycotoxin production in foods. Inter J Food Microbiol 166:1-14. https://doi. org/10.1016/j.ijfoodmicro.2013.05.026

Dambolena JS, Zunino MP, López AG, Rubinstein HR, Zygadlo JA, Mwangi JW, Thoithi GN, Kibwage IO (2010) Essential oils composition of Ocimum basilicum L. and Ocimum gratissimum L. from Kenya and their inhibitory effects on growth and fumonisin production by Fusarium verticillioides. Innov Food Sci Emerg Technol 11:410-414

Döll S, Dänicke S (2011) The Fusarium toxins deoxynivalenol (DON) and zearalenone (ZON) in animal feeding. Prevent Vet Med 102:132-145. https://doi.org/10.1016/j.prevetmed.2011.04.008

Elgorban AM, Bahkali AH, El-Metwally MA, Elsheshtawi M, AbdelWahab MA (2015) In vitro antifungal activity of some plant essential oils. Int J Pharmcol 11(1):56-61. https://doi.org/10.3923/ ijp.2015.56.61

Ellis ML, Munkvold GP (2014) Trichothecene genotype of Fusarium graminearum isolates from soybean (Glycine max) seedling and root diseases in the United States. Plant Dis 98:1012. https://doi. org/10.1094/PDIS-02-14-0150-PDN
Esper RH, Gonçalez E, Marques MOM, Felicio RC, Felicio JD (2014) Potential of essential oils for protection of grains contaminated by aflatoxin produced by Aspergillus flavus. Front Microbiol 5:269. https://doi.org/10.3389/fmicb.2014.00269

Fandohan P, Gbenou JD, Gnonlonfin B, Hell K, Marasas WFO, Wingfield MJ (2004) Effect of essential oils on the growth of Fusarium verticillioides and fumonisin contamination in corn. J Agric Food Chem 52:6824-6829. https://doi.org/10.1021/jf040043p

Feng W, Zheng X (2007) Essential oils to control Alternaria alternata in vitro and in vivo. Food Control 18:1126-1130. https://doi. org/10.1016/j.foodcont.2006.05.017

Foltinová D, Tančinová D, Císarová M (2017) Influence of essential oils on the growth of Aspergillus flavus. Slovak J Food Sci 11:322-331. https://doi.org/10.5219/725

Franco LT, Petta T, Rottinghaus GE, Bordin K, Gomes GA, Oliveira CAF (2018) Co-occurrence of mycotoxins in maize food and maize-based feed from small-scale farms in Brazil: a pilot study. Mycotoxin Res. https://doi.org/10.1007/s12550-018-0331-4

Gabriel KT, Kartforosh L, Crow SA Jr, Cornelison CT (2018) Antimicrobial activity of essential oils against the fungal pathogens Ascosphaera apis and Pseudogymnoascus destructans. Mycopathologia 183(6):921-934. https://doi.org/10.1007/s1104 6-018-0298-x

Gakuubi MM, Maina AW, Wagacha JM (2017) Antifungal activity of essential oil of Eucalyptus camaldulensis Dehnh against selected Fusarium spp. Inter J Microbiol 8761610:7. https://doi. org/10.1155/2017/8761610

Gao T, Zhou H, Zhou W, Hu L, Chen J, Shi Z (2016) The fungicidal activity of thymol against Fusarium graminearum via inducing lipid peroxidation and disrupting ergosterol biosynthesis. Molecules 21(6):770. https://doi.org/10.3390/molecules21060770

Goliński P, Waśkiewicz A, Wiśniewska H, Kiecana I, Mielniczuk E, Gromadzka K, Kostecki M, Bocianowski J, Rymaniak E (2010) Reaction of winter wheat (Triticum aestivum L.) cultivars to infection with Fusarium spp.: mycotoxin contamination in grain and chaff. Food Add Contam 27:1015-1024. https://doi. org/10.1080/19440041003702208

Gömöri C, Nacsa-Farkas E, Kerekes EB, Kocsubé S, Vágvölgyi C, Krisch J (2013) Evaluation of five essential oils for the control of foodspoilage and mycotoxin producing fungi. Acta Biol Szeged 57(2):113-116

Grata K (2016) Sensitivity of Fusarium solani isolated from asparagus on essential oils. Ecol Chem Eng A 23(4):453-464. https://doi. org/10.2428/ecea.2016.23(4)32

Gutarowska B, Żakowska Z (2010) Estimation of fungal contamination of various plant materials with UV-determination of fungal ergosterol. Ann Microbiol 60:415-422. https://doi.org/10.1007/ s13213-010-0057-9

Gwiazdowski R, Gwiazdowska D, Marchwińska K, Juś K, Szutowska J, Bednarek-Bartsch A, Danielewicz B (2018) Fungistatic activity of essential oils towards selected oilseed rape pathogens. Prog Plant Prot 58(4):300-305. https://doi.org/10.14199/ppp-2018-042

Kalagatur NK, Mudili V, Siddaiah C, Gupta VK, Natarajan G, Sreepathi MH, Vardhan BH, Putcha VR (2015) Antagonistic activity of Ocimum sanctum L. essential oil on growth and zearalenone production by Fusarium graminearum in maize grains. Front Microbiol 6:892. https://doi.org/10.3389/fmicb.2015.00892

Kedia A, Prakash B, Mishra PK, Dubey NK (2014) Antifungal and antiaflatoxigenic properties of Cuminum cyminum (L.) seed essential oil and its efficacy as a preservative in stored commodities. Inter J Food Microbiol 168-169:1-7. https://doi.org/10.1016/j. ijfoodmicro.2013.10.008

Kumar V, Mathela CS, Tewari AK, Bisht KS (2014) In vitro inhibition activity of essential oils from some Lamiaceae species against phytopathogenic fungi. Pestic Biochem Phys 114:67-71. https:// doi.org/10.1016/j.pestbp.2014.07.001 
Kumar P, Mishra S, Kumar A, Sharma AK (2016) Antifungal efficacy of plant essential oils against stored grain fungi of Fusarium spp. J Food Sci Technol 53(10):3725-3734. https://doi.org/10.1007/ s13197-016-2347-0

Lang G, Buchbauer G (2012) A review on recent research results (2008-2010) on essential oils as antimicrobials and antifungals. A review. Flavour Frag J 27(1):13-39. https://doi.org/10.1002/ ffj.2082

Lucini EI, Zunino MP, López ML, Zygadlo JA (2006) Effect of monoterpenes on lipid composition and sclerotial development of Sclerotium cepivorum Berk. J Phytopathol 154(7-8):441-446. https://doi.org/10.1111/j.1439-0434.2006.01126.x

Marin S, Velluti A, Ramos AJ, Sanchis V (2004) Effect of essential oils on zearalenone and deoxynivalenol production by Fusarium graminearum in non-sterilized maize grain. Food Microbiol 21:313-318. https://doi.org/10.1016/j.fm.2003.08.002

Matusinsky P, Zouhar M, Pavela R, Novy P (2015) Antifungal effect of five essential oils against important pathogenic fungi of cereals. Ind Crops Prod 67:208-215. https://doi.org/10.1016/j.indcr op.2015.01.022

Mesnage R, Defarge N, Spiroux de Vendômois J, Séralini GE (2014) Major pesticides are more toxic to human cells than their declared active principles. BioMed Res Inter. https://doi. org/10.1155/2014/179691

Montgomery HJ, Monreal CM, Young JC, Seifert KA (2000) Determination of soil fungal biomass from soil ergosterol analyses. Soil Biol Biochem 32:1207-1217

Munhuweyi K, Caleb OJ, Lennox CL, van Reenen AJ, Opara UL (2017) In vitro and in vivo antifungal activity of chitosan-essential oils against pomegranate fruit pathogens. Postharvest Biol Technol 129:9-22

Naeini A, Ziglari T, Shokri H, Khosravi AR (2010) Assessment of growth-inhibiting effect of some plant essential oils on different Fusarium isolates. J Mycol Med 20:174-178. https://doi. org/10.1016/j.mycmed.2010.05.005

Nazzaro F, Fratianni F, Coppola R, De Feo V (2017) Essential oils and antifungal activity. Pharmaceuticals 10(4):86. https://doi. org/10.3390/ph10040086

Nicolopoulou-Stamati P, Maipas S, Kotampasi C, Stamatis P, Hens L (2016) Chemical pesticides and human health: the urgent need for a new concept in agriculture. Front Public Health 4:148. https://doi.org/10.3389/fpubh.2016.00148

Olsson J, Börjesson T, Lundstedt T, Schnürer J (2002) Detection and quantification of ochratoxin A and deoxynivalenol in barley grains by GC-MS and electronic nose. Inter J Food Microbiol 72:203-214. https://doi.org/10.1016/S0168-1605(01)00685-7

Perczak A, Juś K, Marchwińska K, Gwiazdowska D, Waśkiewicz A, Goliński P (2016) Degradation of zearalenone by essential oils under in vitro conditions. Front Microbiol 7:1224. https://doi. org/10.3389/fmicb.2016.01224

Perkowski J, Kiecana I, Kaczmarek Z (2003) Natural occurrence and distribution of Fusarium toxins in 15 naturally-contaminated barley cultivars. Eur J Plant Pathol 109:331-339. https://doi. org/10.1023/A:102354721

Piacentini KC, Rocha LO, Savi GD, Carnielli-Queiroz L, Almeida FG, Minella E, Corrêa B (2018) Occurrence of deoxynivalenol and zearalenone in brewing barley grains from Brazil. Mycotoxin Res 34(3):173-178. https://doi.org/10.1007/s1255 0-018-0311-8

Pietri A, Bertuzzi T, Pallaroni L, Piva G (2004) Occurrence of mycotoxins and ergosterol in maize harvested over 5 years in Northern Italy. Food Add Contam 21:479-487. https://doi. org/10.1080/02652030410001662020

Porep JU, Walter R, Kortekamp A, Carle R (2014) Ergosterol as an objective indicator for grape rot and fungal biomass in grapes. Food Control 37:77-84. https://doi.org/10.1016/j.foodc ont.2013.09.012

Prakash B, Kedia A, Mishra PK, Dubey NK (2015) Plant essential oils as food preservatives to control moulds, mycotoxin contamination and oxidative deterioration of agri-food commoditiespotentials and challenges. Food Control 47:381-391. https://doi. org/10.1016/j.foodcont.2014.07.023

El Ouadi Y, Manssouri M, Bouyanzer A, Majidi L, Bendaif H, Elmsellem H, Shariati MA, Melhaoui A, Hammouti B (2017) Essential oil composition and antifungal activity of Melissa officinalis originating from north-Est Morocco, against postharvest phytopathogenic fungi in apples. Microb Pathog 107:321-326

Raut JS, Karuppayil SM (2014) A status review on the medicinal properties of essential oils. Ind Crops Prod 62:250-264. https://doi. org/10.1016/j.indcrop.2014.05.055

Richardson MD, Logendra S (1997) Ergosterol as an indicator of endophyte biomass in grass seeds. J Agr Food Chem 45:3903-3907. https://doi.org/10.1021/jf970117f

Ruzicka S, Edgerton D, Norman M, Hill T (2000) The utility of ergosterol as a bioindicator of fungi in temperate soils. Soil Biol Biochem 32:989-1005. https://doi.org/10.1016/S0038 -0717(00)00009-2

Santamarina MP, Rosello J, Gimenez S, Blazquez MA (2016) Commercial Laurus nobilis L. and Syzygium aromaticum L. Merr. \& Perry essential oils against post-harvest phytopathogenic fungi on rice. LWT Food Sci Technol 65:325-332. https://doi. org/10.1016/j.1wt.2015.08.040

Saxena J, Munimbazi C, Bullerman L (2001) Relationship of mould count, ergosterol and ochratoxin A production. Inter J Food Microbiol 71:29-34. https://doi.org/10.1016/S0168-1605(01)00584-0

Scherm B, Balmas V, Spanu F, Pani G, Delogu G, Pasquali M, Migheli Q (2013) Fusarium culmorum: causal agent of foot and root rot and head blight on wheat. Mol Plant Pathol 14:323-341. https:// doi.org/10.1111/mpp.12011

Seseni L, Regnier T, van der Roux Merwe MP, Mogale E, Badenhorst J (2015) Control of Fusarium spp. causing damping-off of pine seedlings by means of selected essential oils. Ind Crops Prod 76:329-332. https://doi.org/10.1016/j.indcrop.2015.07.002

Shannon EM, Milillo SR, Johnson MG, Ricke SC (2011) Efficacy of cold-pressed terpeneless valencia oil and its primary components on inhibition of Listeria species by direct contact and exposure to vapors. J Food Sci 76:500-503. https://doi.org/10.11 11/j.1750-3841.2011.02337.x

Shi C, Yan P, Li J, Wu H, Li Q, Guan S (2014) Biocontrol of Fusarium graminearum Growth and Deoxynivalenol Production in Wheat Kernels with Bacterial Antagonists. Int J Environ Res Publ Health 11(1):1094-1105

Singh P, Shukla R, Prakash B, Kumar A, Singh S, Mishra PK, Dubey NK (2010) Chemical profile, antifungal, antiaflatoxigenic and antioxidant activity of Citrus maxima Burm. and Citrus sinensis (L.) Osbeck essential oils and their cyclic monoterpene, dl-limonene. Food Chem Toxicol 48:1734-1740. https://doi. org/10.1016/j.fct.2010.04.001

Solorzano-Santos F, Miranda-Novales MG (2012) Essential oils from aromatic herbs as antimicrobial agents. Curr Opin Biotechnol 23(2):136-141. https://doi.org/10.1016/j.copbio.2011.08.005

Stanisz E, Zgoła-Grześkowiak A, Waśkiewicz A, Stępień Ł, Beszterda M (2015) Can ergosterol be an indicator of Fusarium fungi and mycotoxins in cereal products? J Braz Chem Soc 26(4):705-712. https://doi.org/10.5935/0103-5053.20150030

Stupar M, Grbić ML, Džamić A, Unković N, Ristić M, Jelikić A, Vukojević J (2014) Antifungal activity of selected essential oils and biocide benzalkonium chloride against the fungi isolated from cultural heritage objects. S Afr J Bot 93:118-124

Sumalan RM, Alexa E, Poiana MA (2013) Assessment of inhibitory potential of essential oils on natural mycoflora and Fusarium 
mycotoxins production in wheat. Chem Cent J 7:32. https://doi. org/10.1186/1752-153X-7-32

Tagne A, Amvam Zollo PH, Fontem DA, Mathur B, Neergaard E (2016) Fungicides and essential oils for controlling maize seedborne Fusarium moniliforme and its transmission into seedlings. World J Agr Sci 9(3):290-297. https://doi.org/10.5829/idosi .wjas.2013.9.3.1741

Tian Y, Tan Y, Liu N, Liao Y, Sun C, Wang S, Wu A (2016) Functional agents to biologically control deoxynivalenol contamination in cereal grains. Front Microbiol 7:395. https://doi.org/10.3389/ fmicb.2016.00395

Tumen I, Hafizoglu H, Kilic A, Dönmez IE, Sivrikaya H, Reunanen M (2010) Yields and constituents of essential oil from cones of Pinaceae spp. natively grown in Turkey. Molecules 15:57975806. https://doi.org/10.3390/molecules 15085797

Velluti A, Sanchis V, Ramos AJ, Turon C, Marin S (2004) Impact of essential oils on growth rate, zearalenone and deoxynivalenol production by Fusarium graminearum under different temperature and water activity conditions in maize grain. J Appl Microbiol 96:716-724

Waśkiewicz A, Gromadzka K, Wiśniewska H, Goliński P (2008) Accumulation of zearalenone in genotypes of spring wheat after inoculation with Fusarium culmorum. Cereal Res Commun 36:401-404. http://www.jstor.org/stable/90003249

Weete JD, Gandhi SR (1996) Biochemistry and molecular biology of fungal sterols. In: Esser K, Lemke PA, Brambl R, Marzluf GA (eds) The mycota: a comprehensive treatise on fungi as experimental systems for basic and applied research 1996. Springer, Berlin, pp 421-438
Weete JD, Abril M, Blackwell M, Butler G (2010) Phylogenetic distribution of fungal sterols. PLoS One 5:1-6. https://doi.org/10.1371/ journal.pone.0010899

Xing F, Hua H, Selvaraj JN, Yuan Y, Zhao Y, Zhou L, Liu Y (2014) Degradation of fumonisin $B_{1}$ by cinnamon essential oil. Food Control 38:37-40. https://doi.org/10.1016/j.foodcont.2013.09.045

Yamamoto-Ribeiro MMG, Grespan R, Kohiyama CY, Ferreira FD, Mossini SAG, Silva EL, Junior MM (2013) Effect of Zingiber officinale essential oil on Fusarium verticillioides and fumonisin production. Food Chem 141(3):3147-3152. https://doi. org/10.1016/j.foodchem.2013.05.144

Zabka M, Pavela R, Slezakova L (2009) Antifungal effect of Pimenta dioica essential oil against dangerous pathogenic and toxinogenic fungi. Ind Crops Prod 30:250-253. https://doi.org/10.1016/j.inder op. 2009.04.002

Zaied C, Zouaoui N, Bacha H, Abid S (2012) Natural occurrence of zearalenone in Tunisian wheat grains. Food Control 25:773-777. https://doi.org/10.1016/j.foodcont.2011.12.012

Zain ME (2011) Impact of mycotoxins on humans and animals. J Saudi Chem Soc 15:129-144. https://doi.org/10.1016/j.jscs.2010.06.006

Publisher's Note Springer Nature remains neutral with regard to jurisdictional claims in published maps and institutional affiliations. 